\title{
Grafted Watermelon Root Length Density and Distribution under Different Soil Moisture Treatments
}

\author{
Gilbert Miller ${ }^{1}$ \\ Clemson University, Edisto Research and Education Center, 64 Research \\ Road, Blackville, SC 29817
}

\author{
Ahmad Khalilian \\ School of Agriculture, Forest, and Environmental Sciences, 64 Research \\ Road, Blackville, SC 29817 \\ Jeffrey W. Adelberg \\ School of Agriculture, Forest, and Environmental Sciences, Clemson \\ University, E-143 Poole Agricultural Center, Box 340319, Clemson, SC 29634 \\ Hamid J. Farahani \\ Water Management Engineer, USDA-NRCS East National Technology Support \\ Center, 2901 E. Lee Street, Suite 2100, Greensboro, NC 27401-4901
}

Richard L. Hassell

School of Agriculture, Forest, and Environmental Sciences, Coastal REC, 2700 Savannah Highway, Charleston, SC 29414

Christina E. Wells

Department of Biological Sciences, Clemson University, 150 Long Hall, Clemson, SC 29634

Additional index words. Citrullus lanatus, root zone, capacitance probes, drip irrigation, rootstocks

\begin{abstract}
Delineating the depth and extent of the watermelon [Citrullus lanatus (Thumb.) Matsum. \& Nak.] root zone assists with proper irrigation management and minimizes nutrient leaching. The objective of this 3 -year field study was to measure root distribution and root length density of watermelon (cv. Wrigley) grafted on two different rootstocks (Lagenaria siceraria cv. 'FR Strong' and Cucurbita moschata $\times$ Cucurbita maxima cv. Chilsung Shintoza) and grown under three soil moisture treatments. Irrigation treatments tested were: no irrigation (NI), briefly irrigated for fertigation and earlyseason plant establishment; minimally irrigated (MI), irrigated when soil moisture in top $0.30 \mathrm{~m}$ of soil fell below $50 \%$ available water capacity (AWC); well irrigated (WI), irrigated when soil moisture in top $0.30 \mathrm{~m}$ of soil fell below 15\% (AWC). Root length density (RLD) was measured from $75-\mathrm{cm}$-deep soil cores at two locations three times per growing season and a third location at the end of the season. Cores 1 and 2 sample locations were $15 \mathrm{~cm}$ to the side of each plant: Core 1 on the same side as the drip tape and Core 2 on the opposite side. At the end of the season, Core 3 was taken $15 \mathrm{~cm}$ outside of the bed in bare ground. RLD was significantly greater in the 0 - to $30-\mathrm{cm}$ soil depth and dropped dramatically below $30 \mathrm{~cm}$; it was not significantly affected by irrigation treatment or rootstock. Core 1, next to the drip tape, had greater RLD than Core $2,30 \mathrm{~cm}$ from drip tape, but only at the later sampling dates. Roots were found in Core 3 at all depths, but the RLD was significantly less than that measured in Cores 1 and 2. These findings suggest that the effective root zone depth for watermelon is 0 to $30 \mathrm{~cm}$ and that the particular scion/rootstock combinations tested in this study do not differ in root system size or location.
\end{abstract}

Plant roots play a vital role in the acquisition of belowground resources, yet we have a limited understanding of how they function in natural soil environments (Smit et al., 2000). Both agricultural and non-agricultural water use is increasing globally as are concerns about groundwater contamination from irrigated field leachate (Clothier and Green, 1994). Appropriate irrigation application and the reduction of root zone drainage must be based on accurate delineation of the extent and depth of crop root zones.

The effective root zone (ERZ) depth is the depth of soil used by the main body of the root system for water and nutrient uptake under proper irrigation (Ross and Hardy, 1997). Several studies have highlighted the dominant role of surface roots in extracting soil water. Gardner (1983) determined that soil water extraction dropped off markedly away from the soil surface in a variety of crops. Csizinsky (1979) stated that long drip irrigation durations do not necessarily provide improved lateral movement of water beyond $25 \mathrm{~cm}$ and can result in leaching of fertilizer below the ERZ.

Research has shown that other vegetable crop root systems are relatively shallow when transplanted and grown with drip irrigation under polyethylene mulch. Research in tomato provides some of the most relevant examples. Oliveira and Calado (1996) found that $88 \%$ to $96 \%$ of total tomato root length was present in the top $40 \mathrm{~cm}$ and that RLD decreased rapidly with depth. Bar-Yosef (1977) found $87 \%$ of tomato roots were within a $25-\mathrm{cm}$ lateral and downward distance from the drip emitters on sandy soils. Singh et al. (1989) reported that $74 \%$ of drip-irrigated tomato roots were confined to the top $15 \mathrm{~cm}$ of soil, whereas Machado and Oliveira (2005) found $63 \%$ to $78 \%$ of tomato root length in the top $10 \mathrm{~cm}$.

There is little published information on the root characteristics of watermelon [Citrullus lanatus (Thunb.) Matsum and Nakai] grown under drip irrigation with polyethylene film mulch. An early root study was conducted on the diploid cultivar Kleckly Sweet on bare ground with no irrigation (Weaver and Bruner, 1927). In this case watermelon roots extended $1.2 \mathrm{~m}$ deep, although little root development was found beneath the first foot of soil. More recent studies compared root characteristics of transplanted vs. direct-seeded watermelons (Elmstrom, 1973; NeSmith, 1999). In both cases, transplanted watermelons lacked a taproot and had significantly greater root length than direct-seeded melons, particularly at shallow soil depths.

It is often stated that cucurbit rootstocks have larger root systems than scion varieties (Davis et al., 2008), but specific data quantifying the extent and depth of grafted watermelon root systems are not available. In contrast, many physiological differences between grafted and self-rooted plants have been demonstrated. Pulgar et al. (2000) found that watermelon scions grafted on pumpkin rootstocks showed a higher capacity for nitrogen $(\mathrm{N})$ assimilation, resulting in greater growth in grafted plants. More efficient $\mathrm{N}$ assimilation in grafted Oriental melon and cucumber has been reported (Heo, 1991), and grafted cucumber appears to absorb other nutrients more efficiently than self-rooted plants (Ahn et al., 1999; Gomi and Masuda, 1981; Kim and Lee, 1989). The concentration of cytokinins, which are primarily synthesized in roots, is also higher in the xylem sap of some grafted eggplants (Kato and Lou, 1989). These research findings infer conceivable root system differences in self-rooted and grafted watermelon plants, which need to be delineated to allow for more appropriate irrigation management.

The objectives of this research were (1) to estimate the ERZ for grafted and ungrafted triploid watermelons (Citrullus lanatus cv. Wrigley) grown under polyethylene mulch; and (2) to quantify root distribution and root 
length density of grafted and ungrafted watermelons under adequate and deficient soil moisture treatments. We hypothesized that the main body of the watermelon root system would be found in the upper soil layers and that root length density would increase in all cultivars under reduced irrigation treatment.

\section{Materials and Methods}

Research site and cultural practices. The study was conducted at the Clemson University Edisto Research and Education Center (EREC) near the town of Blackville, SC, in 2008, 2009, and 2010. The field was located at $33^{\circ} 21^{\prime} \mathrm{N}$ latitude and $81^{\circ} 19^{\prime} \mathrm{W}$ longitude and $93 \mathrm{~m}$ above mean sea level. The soil in the 2008-09 test field was Barnwell loamy sand. Natural Resources Conservation Service (U.S. Dept. Agr., Natural Resources Conservation Service, 2012) soil maps indicate that Barnwell loamy sand has a field capacity (FC) of $0.174\left(\mathrm{~cm}^{3} \cdot \mathrm{cm}^{-3}\right)$ and a permanent wilting point (PWP) of $0.061\left(\mathrm{~cm}^{3} \cdot \mathrm{cm}^{-3}\right)$ for the top $30 \mathrm{~cm}$ of soil with an AWC of $\approx 0.113\left(\mathrm{~cm}^{3} \cdot \mathrm{cm}^{-3}\right)$. Soil texture determinations showed sand prevailing to a depth of $20 \mathrm{~cm}$, loamy sand and sand at $30 \mathrm{~cm}$, sandy loam at $40 \mathrm{~cm}$, and sandy clay at $50 \mathrm{~cm}$. The soil in the 2010 test field was classified as Wagram sand with a FC of $0.107\left(\mathrm{~cm}^{3} \cdot \mathrm{cm}^{-3}\right)$, a PWP of $0.045\left(\mathrm{~cm}^{3} \cdot \mathrm{cm}^{-3}\right)$, and an AWC of $\approx 0.062\left(\mathrm{~cm}^{3} \cdot \mathrm{cm}^{-3}\right)$. Soil texture analysis showed sand to a depth of $50 \mathrm{~cm}$.

The winter cover crop of Abruzzi rye (Secale cereal L.) and crimson clover (Trifolium incarnatum L.) was plowed down each year in mid-January. At this time, the field was tilled with bent-leg shanks (WorkSaver's Terra Max, Inc., Litchfield, IL) to a depth of 45 to $50 \mathrm{~cm}$. During early March, preplant fertilizer was applied according to Clemson University soil test recommendations (Franklin and Moore, 2002): $49 \mathrm{~kg} \cdot \mathrm{ha}^{-1}$ of $\mathrm{N}$ and potassium (K) in 2008; $37 \mathrm{~kg} \cdot \mathrm{ha}^{-1}$ of $\mathrm{N}$ and $\mathrm{K}$ in 2009; and $39.2 \mathrm{~kg} \cdot \mathrm{ha}^{-1}$ of $\mathrm{N}$, phosphorus, and $\mathrm{K}$ in 2010.

Each year black polyethylene mulch film (0.019 mm thick, $152.4 \mathrm{~cm}$ wide; Guardian AgroPlastics, Tampa, FL) and drip irrigation tubing (Aqua-Traxx ${ }^{\mathrm{R}}$; Toro Ag Irrigation, El Cajon, CA) were laid 1 week after pre-plant fertilizer application and $30 \mathrm{~d}$ before transplanting. The width of the raised beds covered by polyethylene mulch was $\approx 0.76 \mathrm{~m}$. The drip

\footnotetext{
Received for publication 18 Mar. 2013. Accepted for publication 5 June 2013.

This research was supported by the South Carolina Watermelon Association, National Watermelon Association, Seminis/Monstanto Company, and Earthtec Solutions, LLC. We also acknowledge funding from a USDA-NIFA Special Research Grant.

We thank the many summer students for their help with implementation and data collection for this research and Pat Gerard for his collaboration on the statistical analysis.

${ }^{1}$ To whom reprint requests should be addressed; e-mailgmllr@clemson.edu.
}

tape had an emitter spacing of $0.3 \mathrm{~m}$ with a flow rate of $1.14 \mathrm{lph}$ per emitter at $69 \mathrm{kPa}$.

Plants were transplanted and watered in by hand on 23 Apr. 2008, 15 Apr. 2009, and 15 Apr. 2010. All plots received the same programmed daily irrigation until sensorbased irrigation treatments were initiated on 9 May, 30 Apr., and 29 Apr. in 2008, 2009, and 2010, respectively. Fertigation began on the day of transplanting and was the same for all plots. Fertigation rates ( $\mathrm{N}$ and $\mathrm{K}$ ) per day were low initially $\left(0.56 \mathrm{~kg} \cdot \mathrm{ha}^{-1}\right)$, gradually increased through the growing season $(1.12$ to $1.68 \mathrm{~kg} \cdot \mathrm{ha}^{-1}$ ), and reached a maximum during fruit swell $\left(2.24 \mathrm{~kg} \cdot \mathrm{ha}^{-1}\right)$. Plots were sprayed with fungicides, insecticides, and herbicides as recommended (Keinath and Miller, 2010; Kemble, 2010). Rootstock and scion seed were sowed and tongue-approach grafted (Hassell and Memmott, 2008) in a greenhouse at the EREC. This grafting method originated in The Netherlands (Ishibashi, 1965), does not require a healing chamber, and is now widespread across Europe and Japan (Lee and Oda, 2003). Rootstocks used were 'FR Strong' (Lagenaria spp.) and 'Chilsung Shintoza' (Cucurbita moschata $\times$ Cucurbita maxima).

Irrigation treatments. Three irrigation treatments were tested. Treatment 1 (NI) was briefly irrigated for fertigation and earlyseason plant establishment only. Treatment 2 (MI) and Treatment 3 (WI) were irrigated when soil moisture in the top $0.30 \mathrm{~m}$ of soil fell below $50 \%$ or $15 \%$ available water depletion, respectively. When a given set point was detected, a short-duration irrigation cycle (60 $\min 2008 ; 30 \min 2009$ and 2010) was initiated. The volumetric moisture content (VMC) at which irrigation was triggered in the Barnwell loamy sand (2008-09) was 15.6\% for WI and $11.7 \%$ for MI. The VMC at which irrigation was triggered in the well-drained Wagram sand (2010) was $9.77 \%$ for WI and $7.6 \%$ for MI.

Each whole plot contained a Sentek TriSCAN EasyAg 50-cm soil water capacitance probe (Sentek PTY, Ltd., Kent Town, South Australia), which was integrated within an automated drip irrigation system (EarthTec Solutions LLC, Vineland, NJ). Probes were located immediately adjacent to the drip irrigation tape between the $30-\mathrm{cm}$ spaced emitters. VMC was recorded at 15 -min intervals at 10-, 20-, 30-, 40-, and 50-cm depths and downloaded wirelessly. The irrigation controller used the top three probe readings from each plot to calculate the root zone VMC and trigger irrigations. A Motorola IRRInet Computerized Irrigation Controller (Motorola Inc., Schaumburg, IL) was used to automate irrigation and was coupled with Virtual Network Computing for remote monitoring and editing of ongoing irrigation programs.

Fruit yield and shoot dry weight. Ripe watermelons were harvested based on commonly used field indicators of maturity, including brown tendril located next to the fruit, yellowing on underside of fruit, and a general loss of rind gloss. All fruit were weighed and the total weight $(\mathrm{kg})$ and number (count) of fruit per plot were recorded for all harvests. Four harvests were conducted in 2008 and three harvests in 2009 and 2010. A subsample of five fruit were randomly selected at each harvest for quality measurements, which included length and width of fruit $(\mathrm{cm})$, flesh firmness $(\mathrm{kPa})$, soluble solids $\left({ }^{\circ} \mathrm{Brix}\right)$, number of black seed (count), and hollow heart incidence (length $\times$ width, $\mathrm{cm}^{2}$ ). Immediately before root core sampling at 4,8 , and 12 weeks after planting (WAP), the designated plant for each time period was severed at ground level, harvested, and weighed in the field for fresh shoot weight. Plants were then dried in large ovens to constant mass and shoot dry weight was determined.

Root core sampling. Root core samples were collected from separate designated plants in each plot at $\approx 4,8$, and 12 WAP each year. A tractor-mounted \#10-TS Model GSTS hydraulic sampling and coring machine (Giddings Machine Co., Windsor, CO) was used to take cores to a depth of $75 \mathrm{~cm}$. Plastic tube liners of $4.45 \mathrm{~cm}$ in diameter and $91.44 \mathrm{~cm}$ in length were inserted in the metal coring tube. Two core sample locations were positioned $15 \mathrm{~cm}$ to the side of each plant: Core 1 was always on the same side as the drip tape and Core 2 on the opposite side. At 12 WAP, a third core was taken $15 \mathrm{~cm}$ outside of the bed in the bare ground.

Each core was frozen, cut into five $15-\mathrm{cm}$ segments, and frozen at -4 to $-2{ }^{\circ} \mathrm{C}$ before processing. Roots were separated from soil by hand-washing using a USA Standard Test Sieve (No. 18, $1 \mathrm{~mm}, 0.04$ inches) following the method of Smit et al. (2000). Root samples were refrigerated at $8{ }^{\circ} \mathrm{C}$ in polypropylene vials with two ounces by volume of $50 \%$ ethanol until analysis. Root measurements were performed with WinRHIZO Pro 2009 software (Regent Instruments Inc., Canada) and an Epson STD4800 color scanner (Epson America, Inc., Long Beach, CA). Roots were spread in a $20 \mathrm{~cm} \times 25-\mathrm{cm}$ plastic tray containing a 2- to 3-mm deep layer of water and scanned at a 400 dpi resolution with the TWAIN (Epson America, Inc.) driver interface active. Morphological information acquired from each image included total root length $(\mathrm{cm}), \operatorname{RLD}\left(\mathrm{cm} \cdot \mathrm{cm}^{-3}\right.$ of soil), surface area $\left(\mathrm{cm}^{2}\right)$, and average diameter $(\mathrm{mm})$. After image acquisition, roots were placed in tin foil containers and oven dried at $60{ }^{\circ} \mathrm{C}$ for $48 \mathrm{~h}$ before root dry weight (RDW, g) determination.

Experimental design. The experiment used a split-plot experimental design with irrigation as the main plot factor and plant type as the split-plot factor. The three irrigation treatments were randomly assigned to main plots and replicated four times. Three plant types (Seminis Vegetable Seeds, Inc., St. Louis, MO) were randomly assigned to three split plots within each main plot and included the triploid cultivar Wrigley non-grafted, 'Wrigley'/'FR Strong', and 'Wrigley'/ 'Chilsung Shintoza'.

Each main plot consisted of two raised bed rows spaced $2.44 \mathrm{~m}$ center to center and covered with black polyethylene mulch. One 
raised bed in each split plot contained five treatment plants for yield and fruit quality analysis spaced $0.91 \mathrm{~m}$ apart $\left(2.23 \mathrm{~m}^{2} /\right.$ plant $)$. The second raised bed in each split plot contained five pollenizer plants, diploid cultivar Stargazer (Seminis Vegetable Seeds, Inc.) at the same in-row spacing. Also contained in each split plot were three plants designated for root core sampling and destructive harvest at 4,8 , and 12 WAP. The 4,8 , and 12 WAP designated plants were, respectively, separated from other plants $1.8 \mathrm{~m}, 2.7 \mathrm{~m}$, and $5.5 \mathrm{~m}$. Measurements on each date included: wet and dry shoot biomass, RLD, root mass density, and root surface area. All data were analyzed by analysis of variance with PROC MIXED and PROC GLIMMIX in SAS (SAS Institute Inc., Cary, NC).

\section{Results}

The 3 years did not differ greatly in growing season length, number of growing degreedays $\left(12.8^{\circ} \mathrm{C}\right)$ (Maynard and Hochmuth, 1997), or total daily reference evapotranspiration (Table 1). Precipitation, however, differed markedly among years, ranging from $211 \mathrm{~mm}$ in 2008 to $498 \mathrm{~mm}$ in 2009 . As a result, the amount of water applied in each irrigation treatment differed among years (Table 2). In the wettest year (2009), irrigation was never triggered in the MI treatment, which received the same amount of water as the control (NI) treatment. In 2008 and 2010, more distinct differences among treatments were achieved. The MI treatment received 1.59 and 1.27 times more water than the control in 2008 and 2010, respectively, whereas the WI treatment received 2.50 and 2.16 times more water than the control (Table 2).

Table 1. Environmental conditions for each year of research conducted at the Edisto Research and Education Center in Blackville, SC.

\begin{tabular}{lrrr}
\hline & \multicolumn{3}{c}{ Yr } \\
\cline { 2 - 4 } & 2008 & 2009 & 2010 \\
\hline Season length (days) & 85 & 90 & 82 \\
ETo total (mm) & 435 & 419 & 402 \\
Rainfall total (mm) & 211 & 498 & 337 \\
Growing degree-days & 1723 & 1763 & 1702
\end{tabular}

(12.8 ${ }^{\circ} \mathrm{C}$ base temp)

${ }^{\mathrm{z}}$ Season began at transplanting and ending at final harvest.

ETo $=$ evapotranspiration.
Fruit yield and shoot dry weight. Irrigation significantly increased fruit yield in 2008 and 2010 but had no effect in the very wet 2009 year (Table 3 ). Irrigation significantly increased $(P=0.0013)$ shoot dry weight in 2008 only when dry weights for NI, MI, and WI were $2110 \pm 122 \mathrm{~g}, 2469 \pm 146 \mathrm{~g}$, and $3214 \pm 187 \mathrm{~g} /$ plant, respectively (averaged across all sampling dates). Grafting had no effect on fruit yield or shoot dry weight in any year.

Root length density and soil depth. Despite its marked effect on fruit yield, irrigation treatment had no effect on the RLD $(\mathrm{cm}$ $\operatorname{root} / \mathrm{cm}^{3}$ soil) of 'Wrigley' watermelons in this study. The main effects of plant type and irrigation treatments on RLD were not significant $(P>0.05)$ on any sampling date or when data were pooled by year (Tables 4 and 5 ). Soil depth, however, had a marked effect on RLD: the majority of fine root length was located in the top $30 \mathrm{~cm}$ of soil on all sampling dates. There were significant differences in RLD with depth on all sampling dates in all years (Table 6; Fig. 1). The greatest RLD was measured either in the $0-$ to $15-\mathrm{cm}$ or $15-$ to $30-\mathrm{cm}$ soil depth depending on the year. Although roots did extend as deeply as $75 \mathrm{~cm}$ on every sampling date, $61 \%, 80 \%$, and $85 \%$ of the total root length was found within the top $30 \mathrm{~cm}$ of the core in 2008, 2009, and 2010 , respectively.

The effect of soil depth on RLD differed among irrigation treatments on two occasions. At $56 \mathrm{~d}$ after planting (DAP) in 2008, well-irrigated plants had a greater RLD than the other irrigation treatments in the 0 - to 15-cm soil depth. At 48 DAP in the wet 2009 season, non-irrigated plants had lower RLD than other irrigation treatments in the 15- to $30-\mathrm{cm}$ soil depth. The effect of soil depth on RLD differed among plant types only in 2010 $(P=0.0052)$ when 'FR Strong' had greater RLD in the $15-$ to $30-\mathrm{cm}$ soil depth than the other plant types at 57 and 83 DAP (data not shown).

Root length density and core position. Core position had a significant effect on RLD at the later sampling dates in each year with cores next to the drip tape having $\approx 25.2 \%$ greater root length than those $30 \mathrm{~cm}$ from the drip tape (Tables 4 and 5). At 56 DAP in 2008, the site closest to the emitter (Core 1) had significantly more root length in the 0 - to

Table 2. Irrigation triggers and season water application.

\begin{tabular}{lcccc}
\hline & & \multicolumn{3}{c}{ Treatments } \\
\cline { 2 - 5 } Events & Yr & Well irrigated & Minimally irrigated & No irrigation \\
\hline Number of triggers & 2008 & 88 & 31 & 0 \\
Water applied by triggered irrigation $(\mathrm{mm})^{\mathrm{z}}$ & & 135 & 47 & 0 \\
Total water applied (mm) & 297 & 189 & $119^{\mathrm{y}}$ \\
& & & 0 & 0 \\
Number of triggers & 2009 & 61 & 0 & $94^{\mathrm{y}}$ \\
Water applied by triggered irrigation $(\mathrm{mm})^{\mathrm{z}}$ & & 47 & 94 & 0 \\
Total water applied (mm) & & 141 & 29 & 0 \\
Number of triggers & 2010 & 136 & 22 & $92^{\mathrm{y}}$ \\
Water applied by triggered irrigation $(\mathrm{mm})^{\mathrm{z}}$ & & 104 & 117 & \\
Total water applied (mm) & & 198 & & \\
\hline
\end{tabular}

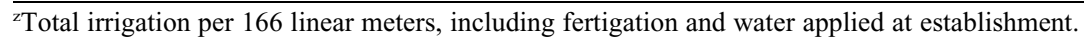

${ }^{\mathrm{y}}$ Includes daily irrigation for fertigation and early-season stand establishment. 15-cm depth than did the site further from the emitter (Core 2). At 83 DAP in 2008 and 2009 , Core 1 had a greater concentration of roots in both the 0 - to 15 - and 15 - to 30 -cm soil depths than Core 2 (Table 7). Similar patterns were also observed in 2010 .

There was no significant interaction between irrigation and core position, but the effect of core position differed among plant types on 57 DAP in $2010(P=0.0038)$. 'FR Strong' RS and 'Chilsung Shintoza' RS had a greater RLD near the drip tape, whereas 'Wrigley' had similar RLD at both core positions 1 and 2. At 83 DAP, an additional Core 3 was taken in the bare ground $15 \mathrm{~cm}$ to the side of planting bed. Roots were found in Core 3 at all depths, but the RLD was significantly less than that measured in Cores 1 and 2 . Across all 3 years, the percentage of the total RLD measured in Core 3 was $16.3 \%$.

Root dry weight. Trends in root dry weight closely paralleled those in root length each year (Fig. 2). The dramatic drop in RDW at the 30- to 45-cm depth in each year is comparable to that seen with RLD. The marked variability of the means (SE bars) seen at the 45- to $60-\mathrm{cm}$ depth in 2009 was the result of several samples having large root pieces.

\section{Discussion}

Watermelon root systems showed marked, consistent reduction in RLD below the $30-\mathrm{cm}$ soil depth in this study. The drop in RLD below the $30-\mathrm{cm}$ soil depth was dramatic each year and on all sampling dates. In the sandy soils of $2010,85 \%$ of the RLD was in the top $30 \mathrm{~cm}$. During the very wet year of $2009,79 \%$ of the RLD was in the top $30 \mathrm{~cm}$. This result is consistent with other studies of vegetables grown on polyethylene mulch with drip irrigation (Bar-Yosef, 1977; Machado and Oliveira, 2005; Oliveira and Calado, 1996; Singh et al., 1989).

Plants' reliance on surface roots for soil water extraction has been well documented. Gardner (1983) pooled a large number of water extraction patterns for various crops and showed that water extraction dropped off substantially away from the surface. Concentration of watermelon roots near the soil surface lends support to the best management practice of high-frequency, short-duration irrigation cycles that maintain soil moisture where it is needed (Clothier and Green, 1994; Rawlings and Raats, 1975).

Table 3. Fruit yield $\left(\mathrm{kg} \cdot \mathrm{ha}^{-1}\right)$ for plants from three irrigation treatments in 2008, 2009, and 2010.

\begin{tabular}{lcrc}
\hline & \multicolumn{3}{c}{ Fruit yield $\left(\mathrm{kg} \cdot \mathrm{ha}^{-1}\right)$} \\
\cline { 2 - 4 } Treatment & 2008 & 2009 & 2010 \\
\hline WI & $138,653 \mathrm{a}^{\mathrm{y}}$ & $100,759 \mathrm{a}$ & $83,862 \mathrm{a}$ \\
MI & $113,090 \mathrm{a}$ & $90,121 \mathrm{a}$ & $50,726 \mathrm{~b}$ \\
NI & $77,197 \mathrm{~b}$ & $86,578 \mathrm{a}$ & $46,145 \mathrm{~b}$ \\
\hline
\end{tabular}

${ }^{\mathrm{z}}$ Experiments were conducted at the Edisto Research and Education Center, Blackville, SC.

${ }^{\mathrm{y}}$ Within a column, different letters denote a significant difference $(P<0.05)$.

$\mathrm{NI}=$ not irrigated; $\mathrm{MI}=$ minimally irrigated; $\mathrm{WI}=$ well irrigated (see "Methods"). 
Table 4. $P$ values of main effects and interactions among irrigation treatment (IRR), grafting type (TYPE), core position relative to the drip tape (CORE), and soil depth (DEPTH) on root length density $\left(\mathrm{cm} \mathrm{root} / \mathrm{cm}^{3}\right.$ soil) of drip-irrigated watermelons.

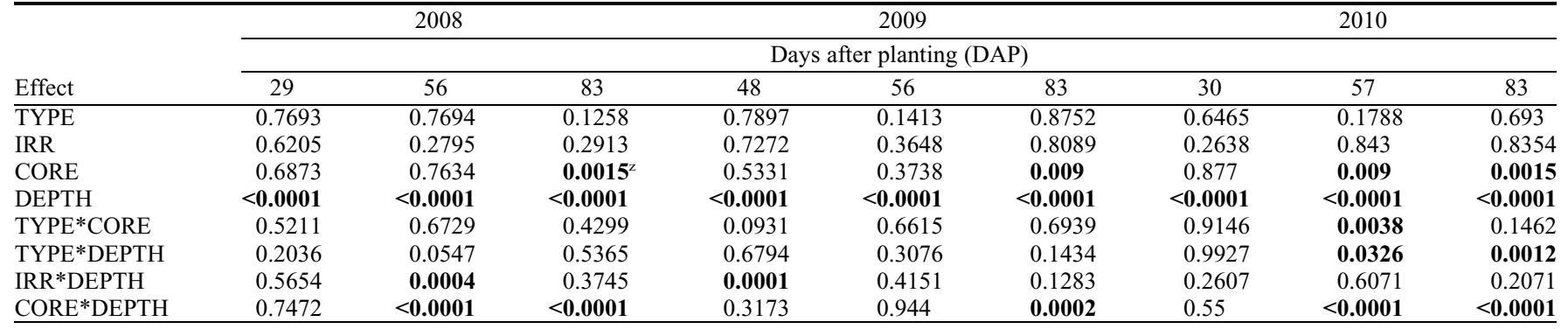

${ }^{\mathrm{z}}$ Bold type represents significant difference $(P<0.05)$.

Table 5. $P$ values of main effects and interactions among irrigation method (IRR), grafting type (TYPE), core position (Core), and soil depth (DEPTH) for root length density $\left(\mathrm{cm} \mathrm{root} / \mathrm{cm}^{3}\right.$ soil) of drip-irrigated watermelons for sampling dates pooled by year.

\begin{tabular}{lrrr}
\hline & 2008 & \multicolumn{1}{c}{2009} & \multicolumn{1}{c}{2010} \\
\cline { 2 - 4 } Effect & \multicolumn{3}{c}{$P$ value } \\
TYPE & 0.3062 & 0.3876 & 0.7507 \\
IRR & 0.1695 & 0.5608 & 0.5922 \\
CORE & 0.1412 & 0.0757 & 0.0023 \\
DEPTH & $<0.0001$ & $<0.0001$ & $<0.0001$ \\
TYPE*DEPTH & 0.7278 & 0.1033 & 0.0052 \\
CORE*DEPTH & $<0.0001$ & 0.3561 & 0.0001 \\
\hline
\end{tabular}

Table 6. Mean root length density $\left(\mathrm{cm} \mathrm{root} / \mathrm{cm}^{3}\right.$ soil) for grafted and self-rooted watermelon plants by year and days after planting (DAP). ${ }^{z}$

\begin{tabular}{clll}
\hline & \multicolumn{3}{l}{2008 root length density $\left(\mathrm{cm} \cdot \mathrm{cm}^{-3}\right)$} \\
\cline { 2 - 4 } Depth $(\mathrm{cm})$ & 29 DAP & 56 DAP & 83 DAP \\
\hline $0-15$ & $0.954 \mathrm{a}^{\mathrm{y}}$ & $1.865 \mathrm{a}$ & $1.817 \mathrm{a}$ \\
$15-30$ & $1.008 \mathrm{a}$ & $1.471 \mathrm{~b}$ & $1.414 \mathrm{~b}$ \\
$30-45$ & $0.431 \mathrm{~b}$ & $0.871 \mathrm{c}$ & $0.621 \mathrm{c}$ \\
$45-60$ & $0.356 \mathrm{bc}$ & $0.959 \mathrm{c}$ & $0.649 \mathrm{c}$ \\
$60-75$ & $0.224 \mathrm{c}$ & $0.732 \mathrm{c}$ & $0.532 \mathrm{c}$
\end{tabular}

\begin{tabular}{cccc} 
& \multicolumn{3}{c}{2009 root length density $\left(\mathrm{cm} \cdot \mathrm{cm}^{-3}\right)$} \\
\cline { 2 - 4 } Depth $(\mathrm{cm})$ & 48 DAP & 56 DAP & 83 DAP \\
\hline $0-15$ & $1.027 \mathrm{a}$ & $1.333 \mathrm{a}$ & $1.466 \mathrm{a}$ \\
$15-30$ & $0.962 \mathrm{a}$ & $1.281 \mathrm{a}$ & $1.266 \mathrm{~b}$ \\
$30-45$ & $0.240 \mathrm{~b}$ & $0.170 \mathrm{~b}$ & $0.224 \mathrm{c}$ \\
$45-60$ & $0.197 \mathrm{c}$ & $0.122 \mathrm{~b}$ & $0.353 \mathrm{c}$ \\
$60-75$ & $0.135 \mathrm{c}$ & $0.073 \mathrm{~b}$ & $0.395 \mathrm{c}$
\end{tabular}

\begin{tabular}{cccc} 
& \multicolumn{3}{c}{2010 root length density $\left(\mathrm{cm} \cdot \mathrm{cm}^{-3}\right)$} \\
\cline { 2 - 4 } Depth $(\mathrm{cm})$ & 29 DAP & 56 DAP & 83 DAP \\
\hline $0-15$ & $1.051 \mathrm{~b}$ & $1.357 \mathrm{a}$ & $1.086 \mathrm{a}$ \\
$15-30$ & $1.617 \mathrm{a}$ & $1.385 \mathrm{a}$ & $1.234 \mathrm{a}$ \\
$30-45$ & $0.209 \mathrm{c}$ & $0.180 \mathrm{~b}$ & $0.210 \mathrm{~b}$ \\
$45-60$ & $0.126 \mathrm{c}$ & $0.104 \mathrm{~b}$ & $0.173 \mathrm{~b}$ \\
$60-75$ & $0.134 \mathrm{c}$ & $0.114 \mathrm{~b}$ & $0.123 \mathrm{~b}$ \\
\hline
\end{tabular}

${ }^{2}$ Research conducted at the Edisto Research and Education Center, Blackville, SC.

${ }^{\mathrm{y}}$ Within columns by year, different letters indicate a significant difference $(P<0.05)$.

We expected to observe differences in RLD and root distribution between grafted and self-rooted watermelon plants. Nonetheless, there were no differences in RLD among grafted and ungrafted watermelons in this study nor were there grafting-related differences in shoot dry weight or yield.

Although numerous publications have claimed that grafted watermelon plants have a more vigorous, wide-ranging root system

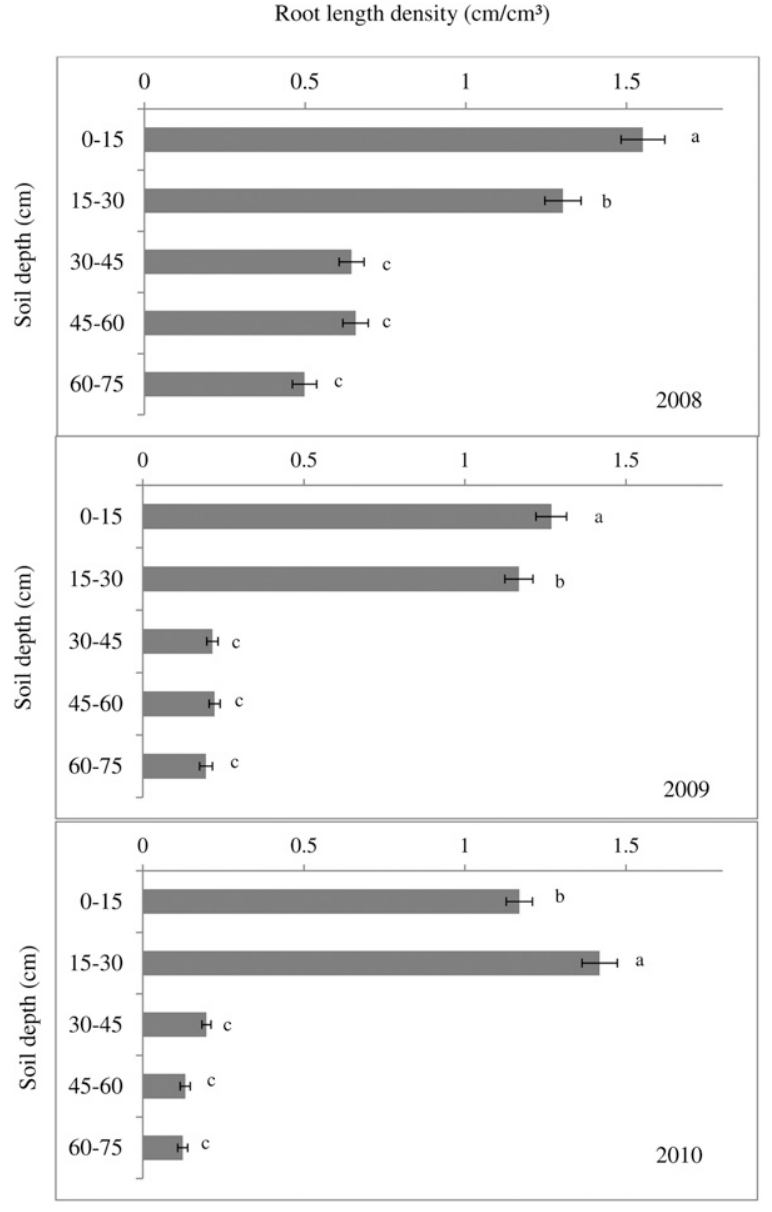

Fig. 1. Mean root length density \pm 1 SE at 15 -cm depth increments in 2008, 2009, and 2010 (data from all sampling dates within a year have been pooled). Within panel, different letters denote a significant difference $(P<0.05)$.

(Lee, 1994), specific data describing the extent and depth of grafted watermelon root systems have not been published. There is tremendous diversity among the genera and species of rootstocks used for watermelon (Ruiz et al., 1997; Sakata et al., 2007), and differences in fruit yield and fruit quality with rootstock have not been consistent (Davis and Perkins-Veazie, 2005-06). Given the large number of possible rootstock/scion combinations, it is premature to generalize that all grafted watermelon plants exhibit larger and stronger root systems.

Both rootstock and scion can have important effects on stomatal performance and carbon partitioning (Ahn et al., 1999; Chen et al., 2002). More vigorous scions may lead to a greater portioning of assimilates to the rootstock and consequently a larger root system. It is possible that the scion, "Wrigley," used in this research was not as vigorous as scions used in previous research and did not provide as great a partitioning of assimilates to the rootstock.

Non-irrigated plants had significantly lower yields than well-irrigated plants but exhibited similar RLDs. This result suggests that watermelon partitions a greater fraction of its assimilates to the root system when water is limiting, an effect that has frequently been noted in other species (Fite et al., 2009; 
Table 7. Mean root length density $\left(\mathrm{cm} \cdot \mathrm{cm}^{-3}\right)$ for core by depth combinations at 56 and $83 \mathrm{~d}$ after planting (DAP) in 2008, 83 DAP in 2009, and 57 and 83 DAP in 2010.

\begin{tabular}{|c|c|c|c|c|c|c|}
\hline \multirow[b]{2}{*}{ Core } & \multirow[b]{2}{*}{ Depth $(\mathrm{cm})$} & \multicolumn{2}{|c|}{2008} & \multirow{2}{*}{$\frac{2009}{83 \mathrm{DAP}}$} & \multicolumn{2}{|c|}{2010} \\
\hline & & 56 DAP & 83 DAP & & 57 DAP & 83 DAP \\
\hline 1 & $0-15$ & $2.174 \mathrm{a}^{\mathrm{z}}$ & $2.240 \mathrm{a}$ & $1.777 \mathrm{a}$ & $1.576 \mathrm{a}$ & $1.400 \mathrm{a}$ \\
\hline 2 & $0-15$ & $1.558 \mathrm{~b}$ & $1.396 \mathrm{bc}$ & $1.156 \mathrm{c}$ & $1.139 \mathrm{~b}$ & $0.773 \mathrm{c}$ \\
\hline 1 & $15-30$ & $1.541 \mathrm{~b}$ & $1.719 \mathrm{~b}$ & $1.463 \mathrm{~b}$ & $1.560 \mathrm{a}$ & $1.351 \mathrm{a}$ \\
\hline 2 & $15-30$ & $1.401 \mathrm{bc}$ & $1.109 \mathrm{c}$ & $1.071 \mathrm{c}$ & $1.211 \mathrm{~b}$ & $1.117 \mathrm{~b}$ \\
\hline
\end{tabular}

Core 1-1.0 $\mathrm{cm}$ from drip tape; Core $2-30 \mathrm{~cm}$ from drip tape.

${ }^{2}$ Within root length density columns by DAP, letters indicate a significant difference $(P<0.05)$.

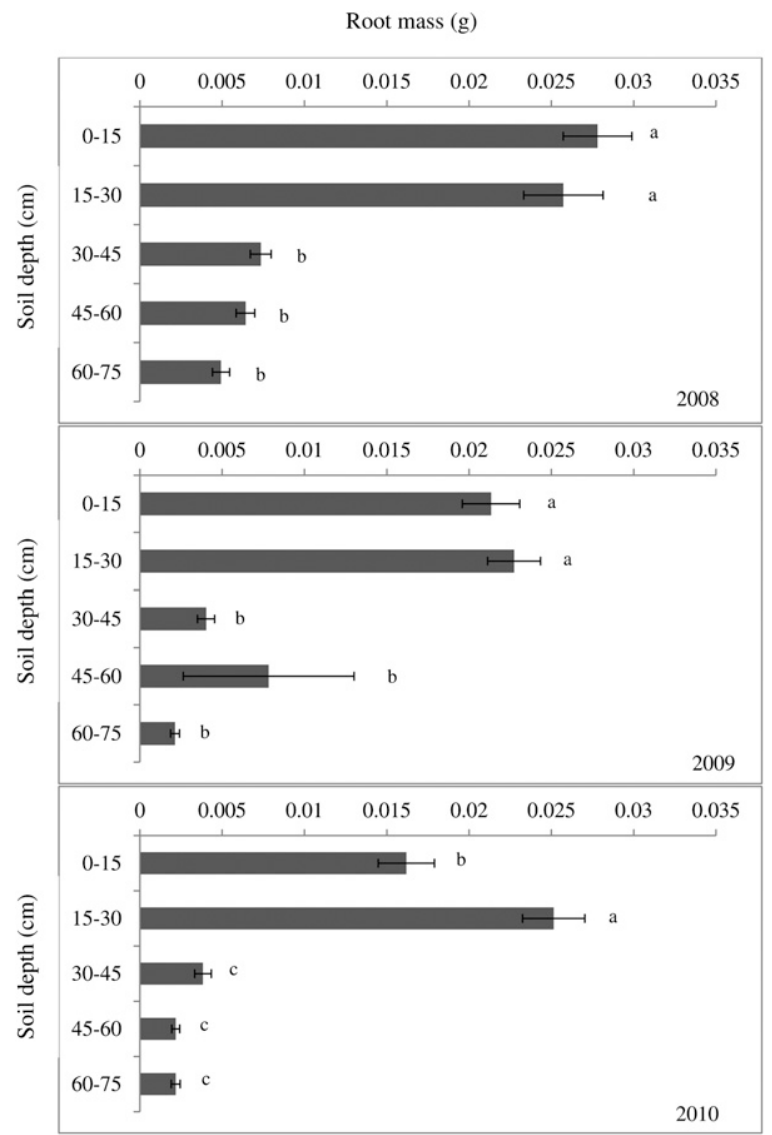

Fig. 2. Mean root dry mass $(\mathrm{g}) \pm 1 \mathrm{SE}$ at 15 -cm depth increments in 2008, 2009, and 2010 (data from all sampling dates within year have been pooled). Within panel, different letters denote a significant difference $(P<0.05)$.

Majdi, 2001). Studies with other crops have shown variable relationships between soil water content and RLD. Searles et al. (2009) showed a significant linear relationship between soil water content and RLD in dripirrigated Argentinian olive orchards under arid conditions. Machado and Oliveira (2005) found no influence of irrigation treatment on tomato root length production when measured with minirhizotrons and only occasional responses when measured with soil cores.

The effect of irrigation briefly differed across soil depths early in the 2008 season, when well-irrigated plants had greater RLD than other plants in the $0-$ to $15-\mathrm{cm}$ depth. At 56 DAP, the plants were maturing fruit, which are major sinks for water and nutrients. It is possible that the proliferation of roots in the upper soil depths at this critical growth stage allowed the plants to acquire greater amounts of nutrients and water, which could have had a bearing on the high watermelon fruit yields during 2008 (Table 3).

Early-season concentration of roots near the drip tape has been documented in other crops (Bar-Yosef, 1977; Machado and Oliveira, 2005). We also observed a greater concentration of roots near the drip tape, but not until later in the season. Only in the sandy soils of 2010 did we see an earlier concentration of RLD near the drip tape at 57 DAP. The earlier concentration of RLD near the drip tape in sandy soils where lateral water movement is reduced was not unexpected.

The interaction between soil depth and core position was notable as the season progressed; there was a tendency for roots to extend deeper at greater distances from the drip tape. This was particularly apparent in the coarse sands of 2010. Although short-duration irrigation cycles were used in this research, it is doubtful whether the horizontal wetting front extended to the 0 - to $15-\mathrm{cm}$ soil depth at core position 2 in 2010. Root concentration in the sandy soils was greatest at the $15-$ to $30-\mathrm{cm}$ soil depth at both core positions.

As indicated by RLD measurements in Core 3 taken $15 \mathrm{~cm}$ to the side of the plant bed in bare ground, roots did extend beyond the polyethylene mulch bed and were found at all depths. Nonetheless, RLD in the bare ground was significantly less than that found in cores under the polyethylene mulch at all depths. Even during 2009 when precipitation was well above normal, root growth beyond the polyethylene mulch bed was minimal.

The RDW analysis reinforces many of the conclusions for RLD. Similar to RLD, RDW was generally greater in the 0 - to $30-\mathrm{cm}$ soil depth at all sampling dates. The analysis of RDW and RLD indicates that the bulk of the watermelon roots is in the top $0-$ to $30-\mathrm{cm}$ soil depth and a precipitous drop in both occurs below the $30-\mathrm{cm}$ soil depth. Neither 'Chilsung Shintoza' RS nor 'FR Strong' RS had greater RLD or showed a propensity to extend roots deeper or further than the nongrafted 'Wrigley'. All plants, grafted or selfrooted, generally responded similarly in root growth and development based on RLD measurements. Irrigation management should endeavor to maintain water and nutrients in the 0 - to 30 -cm soil profile for watermelons grown on polyethylene mulch with drip irrigation.

\section{Literature Cited}

Ahn, S.J., Y.J. Im, G.C. Chung, B.H. Cho, and S.R Suh. 1999. Physiological responses of graftedcucumber leaves and rootstock roots affected by low root temperature. Sci. Hort. 81:397408.

Bar-Yosef, B. 1977. Trickle irrigation and fertilization of tomatoes in sand dunes. Water, $\mathrm{N}$ and $\mathrm{P}$ distribution in the soil and uptake by plants. Agron. J. 69:486-491.

Chen, G.X., S.H. Lips, and M. Sagi. 2002. Biomass production, transpiration rate and endogenous abscisic acid levels in grafts of flacca and wildtype tomato (Lycopersicon esculentum). Funct. Plant Biol. 29:1329-1335.

Clothier, B.E. and S.R. Green. 1994. Rootzone processes and the efficient use of irrigation water. Agr. Water Mgt. 25:1-12.

Csizinsky, A.A. 1979. The importance of irrigation frequency and fertilizer placement in growing vegetables with drip irrigation. Proc. Fla. State Hort. Soc. 92:76-80.

Davis, A.R. and P. Perkins-Veazie. 2005-2006. Rootstock effects on plant vigor and fruit quality. Cucurbit Genet. Coop. Rpt. 28-29:39-42.

Davis, A.R., P. Perkins-Veazie, Y. Sakata, S. LópezGalarza, J.V. Maroto, S.G. Lee, Y.C. Huh, A. Sun, A. Miguel, S.R. King, R. Cohen, and J.M. Lee. 2008. Cucurbit grafting. Crit. Rev. Plant Sci. 27:50-74.

Elmstrom, G.W. 1973. Watermelon root development affected by direct seedling and transplanting. HortScience 8:134-136.

Fite, K.L., E.T. Smiley, and C.E. Wells. 2009. Impacts of root invigoration ${ }^{\mathrm{TM}}$ and its individual components on red maple at four urban sites. In: The landscape belowground III. International Society of Arboriculture, Champaign, IL. 
Franklin, R. and K. Moore. 2002. Nutrient management for South Carolina based on soil test results. Clemson University. Ext. Cir. 476.

Gardner, W.R. 1983. Soil properties and efficient water use: An overview, p. 45-65. In: Limitations to efficient water use in crop production. Am. Soc. Agron., Madison, WI.

Gomi, K. and M. Masuda. 1981. Studies on the characteristics of nutrient absorption of rootstocks on grafting fruit vegetables. I. Magnesium deficiency of leaves of cucumber as affected by a rootstock. C. ficifolia and potassium concentration in culture solution. Bul. Fac. Ag., Miyazaki Univ. Miyazaki, Japan 27:179186.

Hassell, R.L. and F. Memmott. 2008. Grafting methods for cucurbit production. HortScience 43:1677-1679.

Heo, Y.C. 1991. Effect of rootstocks on exudation and mineral elements contents in different parts of oriental melon and cucumber [in Korean with English summary]. MS thesis, Kyung Hee Univ., Seoul, Korea.

Ishibashi, K. 1965. Tongue-approach grafting in cucurbits. Agr. Hort 40:1899-1902 [In Japanese].

Kato, T. and H. Lou. 1989. Effect of rootstock on the yield, mineral nutrition and hormone level in xylem sap in eggplant. J. Jpn. Soc. Hort. Sci. 58:345-352.

Keinath, A.P. and G.A. Miller. 2010. Watermelon spray guide for 2010. Clemson Cooperative Extension Information Leaflet 86. 11 July 2013. $<$ http://www.clemson.edu/psapublishing/Pages/ Plntpath/IL86.pdf>.
Kemble, J. (ed.). 2010. 2010 Vegetable crop handbook for the Southeastern US. Vance Publishing Corp., Lincolnshire, IL.

Kim, S.E. and J.M. Lee. 1989. Effect of rootstocks and fertilizers on the growth and mineral contents in cucumber (Cucumis sativus). Res. Collection, Inst. Food Develop. Kyung Hee Univ. Korea (South) 10:75-82.

Lee, J.M. 1994. Cultivation of grafted vegetables. Current status, grafting methods and benefits. HortScience 29:235-239.

Lee, J.M. and M. Oda. 2003. Grafting of herbaceous vegetable and ornamental crops. Hort. Rev. 28: 61-124.

Machado, R.M.A. and M.D.G. Oliveira. 2005. Tomato root distribution, yield and fruit quality under different subsurface drip irrigation regimes and depths. Irrig. Sci. 24:15-24.

Majdi, H. 2001. Changes in fine root production and longevity in relation to water and nutrient availability in a Norway spruce stand in northern Sweden. Tree Physiol. 21:1057-1061.

Maynard, D.N. and G.J. Hochmuth. 1997. Knott's handbook for vegetable growers. 4th Ed. Wiley, New York, NY.

NeSmith, D.S 1999. Root distribution and yield of direct seeded and transplanted watermelon. J. Amer. Soc. Hort. Sci. 124:458-461.

Oliveira, M.d.R.G. and A.M. Calado. 1996. Tomato root distribution under drip irrigation. J. Amer. Soc. Hort. Sci. 121:644-648.

Pulgar, G., G. Villora, D.A. Morena, and L. Romero. 2000. Improving the mineral nutrition in grafted watermelon plants: Nitrogen metabolism. Biol. Plant. 43:607-609.
Rawlings, S.L. and P.A.C. Raats. 1975. Prospects for high-frequency irrigation. Science 188:604610.

Ross, E.A. and L.A. Hardy. 1997. National engineering handbook; Irrigation guide. USDA, Beltsville, MD.

Ruiz, J.M., A. Belakbir, I. López-Cantarero, and L. Romero. 1997. Leaf-macronutrient content and yield in grafted, melon plants. A model to evaluate the influence of rootstock genotype. Sci. Hort. 71:227-234.

Sakata, Y., O. Takayoshi, and S. Mitsuhiro. 2007. The history and present state of the grafting of cucurbitaceous vegetables in Japan. Acta Hort. 731:159-170.

Searles, P.S., D.A. Saravia, and M.C. Rousseaux. 2009. Root length density and soil water distribution in drip-irrigated olive orchards in Argentina under arid conditions. Crop Pasture Sci. 60:280-288.

Singh, S.D., Y.V. Singh, and R.C. Bhandari. 1989. Tomato yield as related to drip lateral spacing and fertilizer application on total and wetted area basis. Can. J. Plant Sci. 69:991999.

Smit, A.L., A.G. Bengough, C. Engels, M. Van Noordwijk, S. Pellerin, and S.C. Van De Geijn (eds.). 2000. Root methods. Springer, New York, NY.

U.S. Dept. Agr., Natural Resources Conservation Service. 2012. Web soil survey. 10 Feb. 2008. $<$ http://websoilsurvey.nrcs.usda.gov/>.

Weaver, J.E. and W.E. Bruner. 1927. Root development of vegetable crops. McGraw-Hill, New York, NY. 